\title{
Sinonasal neoplasms in 49 dogs: clinical, macroscopic, and histopathological aspects ${ }^{1}$
}

\author{
Giulia F.S. Ricaldi², Morgana M. Hennig ${ }^{3}$, Luís A.S. Tondo ${ }^{3}$, Luiz F. Irigoyen ${ }^{4}$, \\ Rafael A. Fighera ${ }^{4}$ (D) Mariana M. Flores ${ }^{4}$ (D) and Glaucia D. Kommers ${ }^{4 *}$ (D)
}

\begin{abstract}
Ricaldi G.F.S., Hennig M.M., Tondo L.A.S., Irigoyen L.F., Fighera R.A., Flores M.M. \& Kommers G.D. 2020. Sinonasal neoplasms in 49 dogs: clinical, macroscopic and histopathological aspects. Pesquisa Veterinária Brasileira 40(8):621-629. Laboratório de Patologia Veterinária, Departamento de Patologia, Universidade Federal de Santa Maria, Av. Roraima 1000, Cidade Universitária, Camobi, Santa Maria, RS, 97105-900, Brazil. E-mail: glaukommers@yahoo.com

This study aimed to quantify nasosinusal neoplasms diagnosed in dogs in 20 years (2000-2019) and characterize the main clinical, macroscopic, and histological aspects of these neoplasms. The sex, breed, age, skull conformation, the main clinical signs, and the anatomopathological characteristics (distribution, macroscopy, and histology) were computed. During this period, 49 dogs were affected by neoplasms in these regions, totaling 50 neoplasms (one dog had two neoplasms of different locations and histogenetic origins). Similar amounts of mixed-breed dogs (25/49) and purebred dogs (24/49) were affected, these distributed in 16 breeds. Among purebreds, it was noted that dogs with mesocephalic cranial conformation $(12 / 24)$ were the most affected, followed by dolichocephalic $(10 / 24)$ and brachycephalic $(2 / 24)$. There were 22 cases in males and 27 in females, making a proportion of 1:1.23. There was an age variation from 11 months to 16 years old. The epithelial neoplasms have occurred in older dogs compared to those of other histogenic origins (mesenchymal and other origins/ round cells). The main clinical signs were similar between the histogenetic categories, related to the involvement of the upper respiratory tract, sometimes accompanied by nervous signs (when there was brain invasion of nasal neoplasms or vice versa). The possible origin site was mostly in the nasal cavity concerning the paranasal sinuses (and other locations). Invasions occurred in different tissues adjacent to the nasal cavity and paranasal sinuses, resulting in cranial and facial deformities (21/49). The frequency was $48 \%$ of epithelial neoplasms, $32 \%$ of mesenchymal neoplasms, and $10 \%$ of neoplasms with other origins and round cells. The neoplasms most frequently observed, in decreasing order of frequency, were: adenocarcinoma (9/50), squamous cell carcinoma (9/50), transmissible venereal tumor (5/50), osteosarcoma (5/50), chondrosarcoma (4/50), and undifferentiated sarcoma (4/50). Through this study, it was possible to establish the frequency of these neoplasms in 20 years and their clinical, macroscopic, and histological characteristics.
\end{abstract}

INDEX TERMS: Sinonasal neoplasm, dogs, clinic, macroscopy, histopathology, nasal cavity, paranasal sinuses, upper respiratory tract, canine.

\section{RESUMO.- [Neoplasmas nasossinusais em 49 cães:} aspectos clínicos, macroscópicos e histopatológicos.] Este estudo teve como objetivo quantificar os neoplasmas nasossinusais diagnosticados em cães em 20 anos (2000-2019)

\footnotetext{
${ }^{1}$ Received on May 20, 2020.

Accepted for publication on June 8, 2020.

Part of Master's Thesis of the first author.

${ }^{2}$ Graduate Program in Veterinary Medicine with emphasis in Pathology and Veterinary Clinical Pathology, Centro de Ciências Rurais (CCR), Universidade Federal de Santa Maria (UFSM), Av. Roraima 1000, Camobi, Santa Maria, RS 97105-900, Brazil.
}

e caracterizar os principais aspectos clínicos, macroscópicos e histológicos desses neoplasmas. Foram computados sexo, raça, idade, conformação do crânio, principais sinais clínicos e características anatomopatológicas (distribuição, macroscopia

\footnotetext{
${ }^{3}$ Curso de Medicina Veterinária, Centro de Ciências Rurais (CCR), Universidade Federal de Santa Maria (UFSM), Av. Roraima 1000, Camobi, Santa Maria, RS 97105-900, Brazil.

${ }^{4}$ Laboratório de Patologia Veterinária, Departamento de Patologia, Centro de Ciências da Saúde, Universidade Federal de Santa Maria (UFSM), Av. Roraima 1000, Camobi, Santa Maria, RS 97105-900, Brazil. *Corresponding author: glaukommers@yahoo.com
} 
e histologia). Nesse período, 49 cães foram acometidos por neoplasmas nessas regiões, totalizando 50 neoplasmas (um cão tinha dois neoplasmas de localização e origens histogenéticas distintas). Foram acometidas quantidades semelhantes de cães sem raça definida $(25 / 49)$ e de cães com raça definida (24/49), estes distribuídos em 16 raças. Entre os cães com raça definida, notou-se que os cães com conformação craniana mesocefálica (12/24) foram os mais acometidos, seguidos pelos dolicocefálicos $(10 / 24)$ e braquicefálicos $(2 / 24)$. Foram observados 22 casos em machos e 27 em fêmeas, perfazendo a relação de 1:1,23. Ocorreu uma variação de idade de 11 meses a 16 anos; tendo os neoplasmas epiteliais ocorrido em cães mais velhos quando comparado aos de outras origens histogênicas (mesenquimais e outras origens/células redondas). Os principais sinais clínicos foram semelhantes entre as categorias histogenéticas, sendo relacionados ao comprometimento do trato respiratório superior, por vezes acompanhados de sinais nervosos (quando houve invasão encefálica de neoplasmas nasais ou vice-versa). 0 possível local de origem em sua maioria foi na cavidade nasal em relação aos seios nasais (e de outras localizações). Ocorreram invasões para diferentes tecidos adjacentes à cavidade nasal e seios paranasais, tendo como consequência deformidades cranianas e faciais $(21 / 49)$. A frequência foi de $48 \%$ de neoplasmas epiteliais, $32 \%$ de neoplasmas mesenquimais e $10 \%$ de neoplasmas com outras origens e de células redondas. Os neoplasmas mais frequentemente observados, em ordem decrescente de frequência, foram: adenocarcinoma $(9 / 50)$, carcinoma de células escamosas $(9 / 50)$, tumor venéreo transmissível $(5 / 50)$, osteossarcoma $(5 / 50)$, condrossarcoma $(4 / 50)$ e sarcoma indiferenciado (4/50). Com isso, pode-se estabelecer a frequência desses neoplasmas em 20 anos, bem como suas características clínicas, macroscópicas e histológicas.

TERMOS DE INDEXAÇÃO: Neoplasma nasossinusal, cão, clínica, macroscopia, histopatologia, cavidade nasal, seios paranasais, trato respiratório superior, caninos.

\section{INTRODUCTION}

Nasosinusal neoplasms in dogs occur with rare frequency. Estimate that for every 100,000 dogs, only 2.5 have some neoplasm in the nasal cavity or paranasal sinuses (Wilson 2017). Lobetti (2009) showed that in 75 cases of dogs with chronic nasal diseases, $46.7 \%$ had some neoplasm that affected the nasal cavity; however, compared to all tumors that can affect dogs, its prevalence was between $0.3 \%$ and $1.4 \%$ (Ogilvie \& Larue 1992). These data demonstrate how unusual it is to have nasosinusal neoplasms, both when related to the total population of dogs, and when compared among all tumors that affect this animal species.

The nasal cavity and sinuses are composed and directly related to different tissues, including the epithelia that line the nasal cavity and sinuses, as well as underlying bone and cartilage tissue. The epithelia in the nasal cavity vary between stratified nasal epithelium in the most rostral portion, the pseudostratified ciliated columnar epithelium, and, in the more caudal region, the olfactory epithelium (Bacha \& Bacha 2012, Evans \& Lahunta 2013). The sinus epithelium is composed of pseudo-stratified ciliated epithelium, with few goblet cells (König \& Liebich 2011, Junqueira \& Carneiro 2013). Because of this, neoplasms of different embryonic origins may arise, resulting in a large histogenetic variety of tumors in this region, which may vary according to the anatomical region affected (Wilson 2017).

Information regarding the frequency of occurrence of these neoplasms in the Brazilian literature has been limited mainly to case reports (Canal et al. 2006, Formighieri et al. 2012, Gonçalves et al. 2012). However, studies with a more expressive series are scarce (Auler 2010, Dadalto et al. 2019).

This study aimed to quantify nasosinusal neoplasms diagnosed in dogs at the "Laboratório de Patologia Veterinária" of the "Universidade Federal de Santa Maria" (UFSM) over 20 years and characterize the main clinical, macroscopic, and histological aspects of these neoplasms.

\section{MATERIALS AND METHODS}

All cases of neoplasms affecting the nasal cavity and/or nasal sinuses (nasosinusal neoplasms) in dogs were compiled, both from necropsies and biopsies analyzed at the "Laboratório de Patologia Veterinária" (LPV) of the "Universidade Federal de Santa Maria" (UFSM) from January 2000 to December 2019 (20 years). The number of necropsies and biopsies of the canine species received in the same period were also computed.

The data regarding the age, sex, breed, size, the cranial conformation of the dogs, and the clinical signs were obtained from the biopsy and necropsy protocols of the LPV-UFSM files. For purebred dogs, the classification was made according to the skull conformation in brachycephalic, mesocephalic, and dolichocephalic dogs, according to the characteristics described for each breed by the "Confederação Brasileira de Cinofilia" (CBKC 2019) and by the American Kennel Club (AKC 2019).

The macroscopic aspects, including the distribution of the lesions (considering the possible site of origin, invasion, and metastases), macroscopic descriptions, and the morphological diagnoses were based on what was contained in each protocol. Based on histopathological diagnoses, they were grouped according to histogenesis into epithelial, mesenchymal, or other neoplasms and round cells, according to the system proposed by Wilson (2017) and adapted according to Caswell \& Williams (2016). The macroscopic characteristics were complemented by the photographs of the cases from the photographic collection of the LPV-UFSM.

In cases where paraffin blocks were available in the LPV-UFSM files, new histological slides were made to reassess the microscopic characteristics in selected cases, mainly when the neoplasm subtype had not been classified.

In some of these cases where a subclassification had not been defined, hematoxylin and eosin (HE) stain and the immunohistochemistry (IHC) techniques were also used to define the diagnosis better. The IHC technique was performed in three cases diagnosed as undifferentiated sarcoma. All sections were subjected to dewaxing and rehydration, blocking endogenous peroxidase with $3 \%$ hydrogen peroxide $\left(\mathrm{H}_{2} \mathrm{O}_{2}\right)$ (2x times for $10 \mathrm{~min}$.). Subsequently, antigen retrieval was performed with Tris-EDTA ( $\mathrm{pH}$ 9.0) in a microwave oven (for $10 \mathrm{~min}$. at full power) and blocking of non-specific reactions using casein (skimmed-milk powder). Primary antibodies were used in dilutions of 1:2,000 (pan cytokeratin; epithelial cell marker), 1:100 (vimentin; mesenchymal cell marker), 1:200 (KIT; mast cell marker), 1:200 (CD3; T lymphocyte marker), 1:100 (CD79 $\alpha c y ; \mathrm{B}$ lymphocyte marker) and 1:500 (MAC-387; macrophage marker), all of which were incubated in a humid chamber at $37^{\circ} \mathrm{C}$ for 1 hour. Later, the EasyLink-One polymer (EasyPath) was used at $25^{\circ} \mathrm{C}$ for $20 \mathrm{~min}$. As a chromogen, 3,3'diaminobenzidine (DAB) was used. 
Harris hematoxylin was used as a counter-stain. As positive controls, previously tested cases for the respective antibodies were used, and as negative controls, only PBST was used in the tested sections.

\section{RESULTS}

From January 2000 to December 2019, 5,365 dogs were necropsied, and 11,489 biopsies of the same species were received, totaling 16,854 samples from canines. Forty-nine cases of nasosinusal neoplasms were accounted for, 29 from necropsies and 20 from biopsies, making up $0.29 \%$ of all dogs analyzed in the 20 years of the study.

Of the 49 dogs that had a nasosinusal neoplasm, twenty-seven (55\%) were female, and twenty-two (45\%) were male. About a half $(51 \%)$ of the dogs were classified as mixed-breed. Of the 24 (49\%) dogs that were purebred (distributed in 16 breeds), most dogs were classified as large breeds (63\%), followed by small dogs (21\%), giant dogs (13\%), and medium-sized dogs (4\%). Dogs were classified according to their skull shape: $8 \%$ were brachycephalic $(2 / 24), 50 \%$ were mesocephalic $(12 / 24)$, and $42 \%$ were dolichocephalic (10/24).

The clinical signs observed in dogs with neoplasms from the three histogeneses (epithelial, mesenchymal, and other origins/round cells) were similar. They mainly had an increase in volume in the nasal region (unilateral or bilateral) (21/49), causing partial or total obstruction of the nasal cavity; the presence of nasal discharge (9/49), sometimes bloody (14/49); difficulty breathing (7/49); sneezing (4/49) and coughing (1/49). Due to the invasion of some neoplasms to the adjacent tissues (mainly to the brain), the dogs showed less specific clinical signs of respiratory impairment, such as seizures (4/49), blindness $(3 / 49)$, reduction in the level of consciousness (2/49), behavior change (1/49), howls (1/49), nystagmus (1/49), and proprioceptive deficiency $(1 / 49)$. Additionally, there was an increase in volume in the skull region (2/49) and atrophy of the skull muscles (1/49).

In the 49 dogs, 50 tumors affecting the nasal cavity and/or the sinuses were counted. Of the 50 neoplasms, twenty-four were of epithelial origin (48\%), sixteen were of mesenchymal origin (32\%), and ten were of other origins/round cells (20\%). One dog simultaneously presented two different types of neoplasms affecting the nasal cavity (undifferentiated sarcoma) and the frontal sinuses (adenocarcinoma). The macroscopic, histopathological, and immunohistochemical aspects of this case are illustrated in Figures 1 and 2. Of the 50 neoplasms, three were submitted to immunohistochemistry because they had a diagnosis of undifferentiated sarcoma. When submitted to IHC, all cases were positive for vimentin, and one case was also positive for CD3 (T lymphocyte marker). All tested cases were negative for the other antibodies. Four cases of carcinomas that had no subclassification were histologically reassessed. Of these cases, three were classified as adenocarcinomas and one as undifferentiated carcinoma, based on their morphological characteristics. Data on age, breed, distribution of neoplasms, and macroscopy were grouped according to the three histogenetic groups and will be detailed below.

\section{Epithelial neoplasms}

The 24 neoplasms of epithelial origin were diagnosed in twelve mixed-breed and twelve purebred dogs. The distribution between the breeds was heterogeneous and consisted of: three
Rottweilers and one specimen each of the breeds: Cocker Spaniel, Weimaraner, Fila Brasileiro, Great Dane, Poodle, Saint Bernard, Boxer, German Shepherd, and Dachshund. Of the 21 cases in which the age was informed in the protocols, it ranged from 3 to 16 years, with an average of 10.33 years and a median of 10 years.

Histological subtypes and the distribution of neoplasms (considering the possible site of origin, invasion, and metastasis) are shown in Table 1. Among the epithelial neoplasms, nineteen had as probable site of origin, the nasal cavity, two in the sinuses, and three in other regions (nostril, skin, and palate). The main macroscopic and histological characteristics are detailed in Table 2.

Eleven cases were observed in which the neoplasms caused deformities in the head and/or face of the dogs. Of these cases, five were of squamous cell carcinoma, two of adenocarcinoma, two of transitional carcinoma, one case of neuroendocrine carcinoma, and one of adenosquamous carcinoma.

Table 1. Histological type, number of cases, and distribution of nasosinusal neoplasms with epithelial origin

\begin{tabular}{|c|c|c|}
\hline Neoplasm & $\begin{array}{c}\text { No. of cases } \\
(\%)\end{array}$ & Distribution \\
\hline \multirow[t]{7}{*}{ Adenocarcinoma } & $9(18 \%)$ & (3) Nasal cavity ${ }^{\mathrm{PL}}$ \\
\hline & & $\begin{array}{l}{ }^{(1)} \text { Nasal cavity }{ }^{\mathrm{PL}} \text {, frontal sinus }{ }^{\mathrm{I}} \text {, jaw }{ }^{\mathrm{I}} \\
\text { and nasal bone }{ }^{\mathrm{I}}\end{array}$ \\
\hline & & $\begin{array}{l}{ }^{(1)} \text { Nasal cavity }{ }^{\mathrm{PL}} \text {, frontal sinus }{ }^{\mathrm{I}} \text {, nasal } \\
\text { bone }{ }^{\mathrm{I}} \text {, palate }{ }^{\mathrm{I}} \text { and gum }{ }^{\mathrm{I}}\end{array}$ \\
\hline & & $\begin{array}{l}\text { (1) Nasal cavity }{ }^{\mathrm{PL}} \text {, soft palate }{ }^{1} \text {, brain }{ }^{\mathrm{I}} \\
\text { and frontal sinus }{ }^{1}\end{array}$ \\
\hline & & $\begin{array}{l}{ }^{(1)} \text { Nasal cavity }{ }^{\mathrm{PL}} \text {, hard palate }{ }^{\mathrm{I}} \text {, lung }{ }^{\mathrm{M}} \text { and } \\
\text { submandibular lymph node }{ }^{\mathrm{M}}\end{array}$ \\
\hline & & $\begin{array}{l}{ }^{(1)} \text { Nasal cavity }{ }^{\mathrm{PL}} \text {, nasal bone }{ }^{\mathrm{I}} \text {, palate }{ }^{\mathrm{I}} \text {, } \\
\text { nasopharynx }{ }^{\mathrm{I}} \text { and lung }{ }^{\mathrm{M}}\end{array}$ \\
\hline & & $\begin{array}{l}{ }^{(1)} \text { Nasal sinus }{ }^{\mathrm{PL}} \text {, frontal bone }{ }^{\mathrm{I}} \text {, temporal } \\
\text { bone }^{\mathrm{I}} \text { and temporal muscles }{ }^{1 *}\end{array}$ \\
\hline \multirow{8}{*}{$\begin{array}{l}\text { Squamous cell } \\
\text { carcinoma }\end{array}$} & $9(18 \%)$ & ${ }^{(2)}$ Nasal cavity ${ }^{\mathrm{PL}}$ \\
\hline & & $\begin{array}{l}{ }^{(1)} \text { Nasal cavity }{ }^{\mathrm{PL}} \text {, brain }{ }^{\mathrm{I}} \text {, soft palate }{ }^{\mathrm{I}} \text {, } \\
\text { and lung }{ }^{\mathrm{M}}\end{array}$ \\
\hline & & $\begin{array}{l}\text { (1) Nasal cavity }{ }^{\mathrm{PL}} \text {, hard palate }{ }^{\mathrm{I}} \text {, soft } \\
\text { palate }{ }^{\mathrm{I}} \text {, and jaw }{ }^{\mathrm{I}}\end{array}$ \\
\hline & & ${ }^{(1)}$ Nasal cavity ${ }^{\mathrm{PL}}$ and jaw ${ }^{\mathrm{I}}$ \\
\hline & & $\begin{array}{l}\text { (1) Nasal cavity }{ }^{\mathrm{PL}} \text {, frontal bone }{ }^{\mathrm{I}} \text { and } \\
\text { nasal bone }{ }^{\mathrm{I}}\end{array}$ \\
\hline & & (1) Palate ${ }^{\mathrm{PL}}$, frontal sinus ${ }^{\mathrm{I}}$ and jaw ${ }^{\mathrm{I}}$ \\
\hline & & $\begin{array}{l}{ }^{(1)} \text { Nostril }{ }^{\mathrm{PL}} \text {, nasal cavity }{ }^{\mathrm{I}} \text {, nasal plane }{ }^{\mathrm{I}} \text {, } \\
\text { nasopharynd }{ }^{\mathrm{I}} \text { and frontal sinus }{ }^{\mathrm{I}}\end{array}$ \\
\hline & & ${ }^{(1)}$ Skin $^{\mathrm{PL}}$ and nasal cavity ${ }^{\mathrm{I}}$ \\
\hline \multirow{2}{*}{$\begin{array}{l}\text { Transitional } \\
\text { carcinoma }\end{array}$} & $2(4 \%)$ & (1) Nasal cavity ${ }^{\mathrm{PL}}$ and adrenal ${ }^{\mathrm{M}}$ \\
\hline & & $\begin{array}{l}{ }^{(1)} \text { Frontal sinus }{ }^{\mathrm{PL}} \text {, frontal bone }{ }^{\mathrm{I}} \text {, parietal } \\
\text { bone }{ }^{\mathrm{I}} \text {, brain }{ }^{\mathrm{I}} \text { and retropharyngeal } \\
\text { lymph nodes }{ }^{\mathrm{M}}\end{array}$ \\
\hline \multirow{2}{*}{$\begin{array}{l}\text { Undifferentiated } \\
\text { carcinoma }\end{array}$} & $2(4 \%)$ & ${ }^{(1)}$ Nasal cavity ${ }^{\mathrm{PL}}$ \\
\hline & & ${ }^{(1)}$ Nasal cavity ${ }^{\mathrm{PL}}$ and frontal sinus ${ }^{1}$ \\
\hline $\begin{array}{l}\text { Adenosquamous } \\
\text { carcinoma }\end{array}$ & $1(2 \%)$ & $\begin{array}{l}{ }^{(1)} \text { Nasal cavity }{ }^{\mathrm{PL}} \text {, frontal sinus }{ }^{1} \text {, frontal } \\
\text { bone }{ }^{\mathrm{I}} \text {, parietal bone }{ }^{\mathrm{I}} \text { and brain }{ }^{1}\end{array}$ \\
\hline $\begin{array}{l}\text { Neuroendocrine } \\
\text { carcinoma }\end{array}$ & $1(2 \%)$ & $\begin{array}{l}\text { (1) Nasal cavity }{ }^{\mathrm{PL}} \text {, nasal bone }{ }^{\mathrm{I}} \text {, jaw }{ }^{\mathrm{I}} \text {, } \\
\text { frontal bone }{ }^{\mathrm{I}} \text {, brain }{ }^{\mathrm{I}} \text { and frontal sinus }\end{array}$ \\
\hline TOTAL & $24 / 50(48 \%)$ & \\
\hline
\end{tabular}




\section{Mesenchymal neoplasms}

The 16 neoplasms of mesenchymal origin were diagnosed in seven mixed-breed dogs and in nine purebred dogs (Dalmatian, Akita, Shetland Shepherd, Boxer, Collie, Fila Brasileiro, Pinscher, and two Rottweilers). Of the sixteen dogs, only in one case, the age was not informed. The age of the 15 dogs ranged from 11 months to 14 years, with an average of 7.79 years and a median of 8 years. The youngest dog in this study (11 months) had undifferentiated sarcoma, interpreted as multicentric.
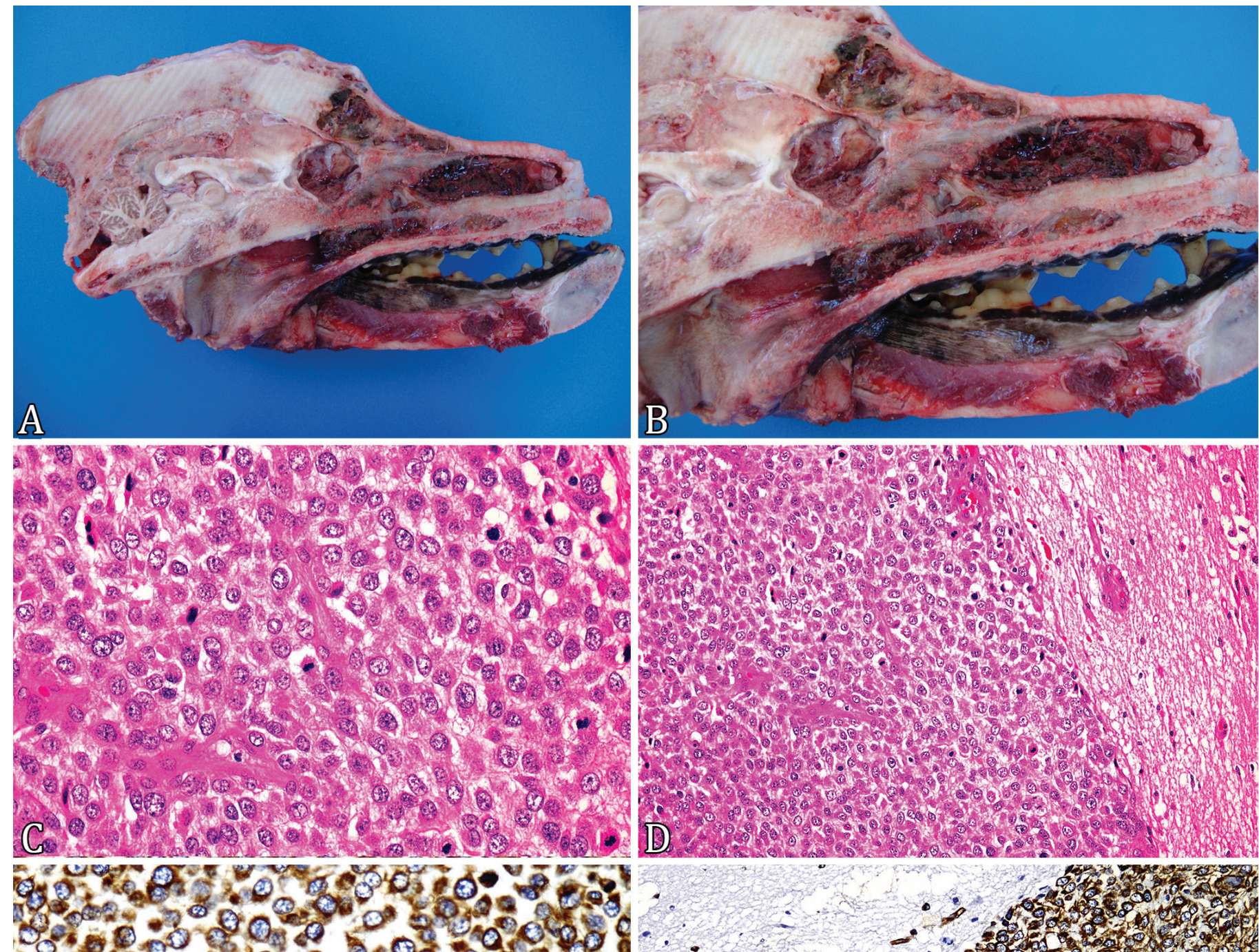

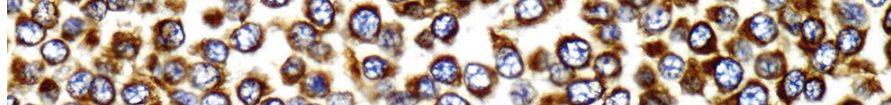

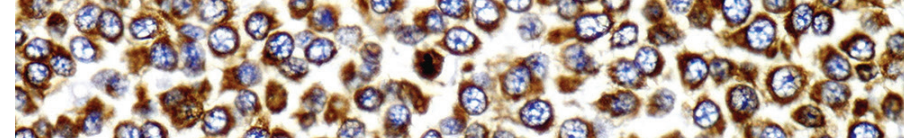

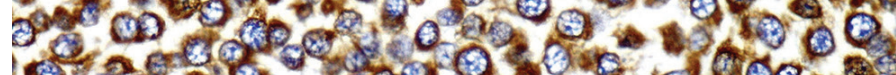
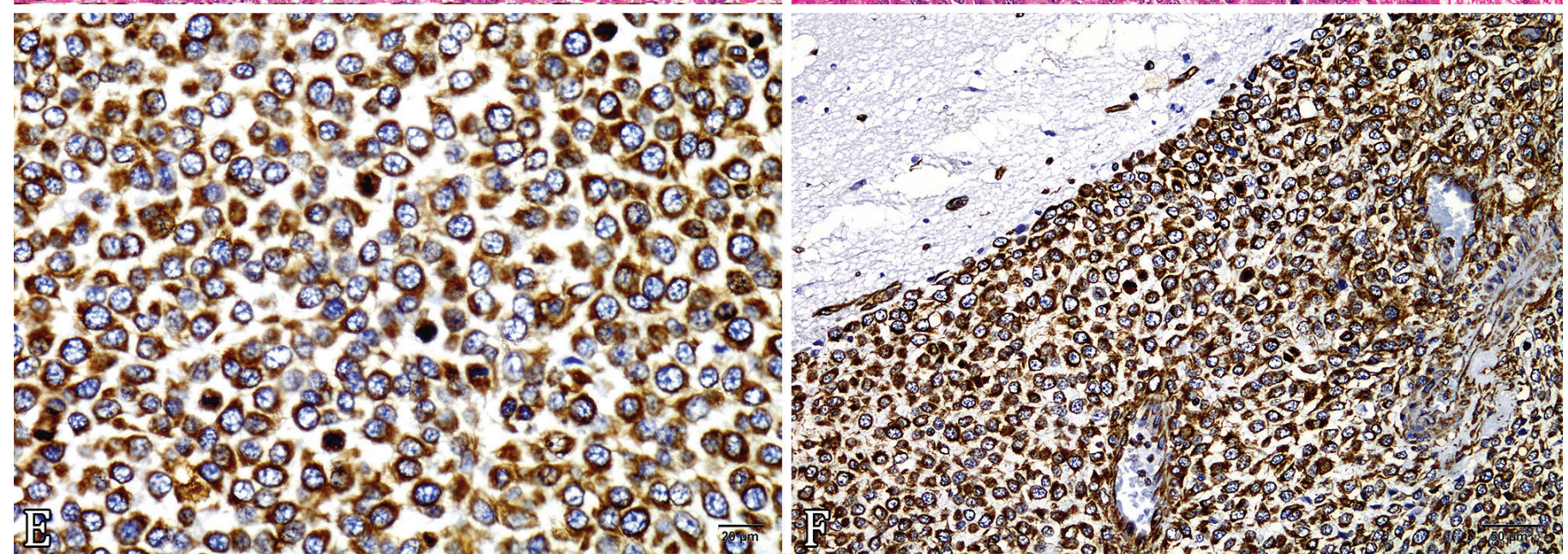

Fig.1. Undifferentiated sarcoma. (A) The nasal cavity is filled with a friable, reddish mass that invades the pharynx and crosses the ethmoidal region invading the cranial cavity. (B) Approximation of Figure 1A, showing the invasion of brain tissue in the frontal cortex region. (C) Neoplasm consisting of a solid mantle of large cells, round to polygonal, with moderate to severe pleomorphism. $\mathrm{HE}$, bar $=20 \mu \mathrm{m}$. (D) Brain invasion of the neoplastic cells described in Figure 1C. HE, bar $=50 \mu \mathrm{m}$. (E-F) Immunohistochemistry for vimentin (streptavidinbiotin-peroxidase method). Neoplastic cells strongly immunostained in the nasal mass (E) and brain invasion (F) are observed. (E) IHC, bar $=20 \mu \mathrm{m}$. (F) IHC, bar $=50 \mu \mathrm{m}$. 
Histological subtypes and neoplasm distribution (considering the possible site of origin, invasion, and metastasis) are shown in Table 3. Among the mesenchymal neoplasms, 12 had a probable place of origin in the nasal cavity, three in other regions (two in the maxilla and one in the palate), and one was multicentric. The main macroscopic and histological characteristics are described in Table 4.

Seven cases were observed in which the neoplasms caused deformities in the head and/or face. Of the seven dogs, four were diagnosed with osteosarcoma, two with chondrosarcoma, and one with fibrosarcoma.
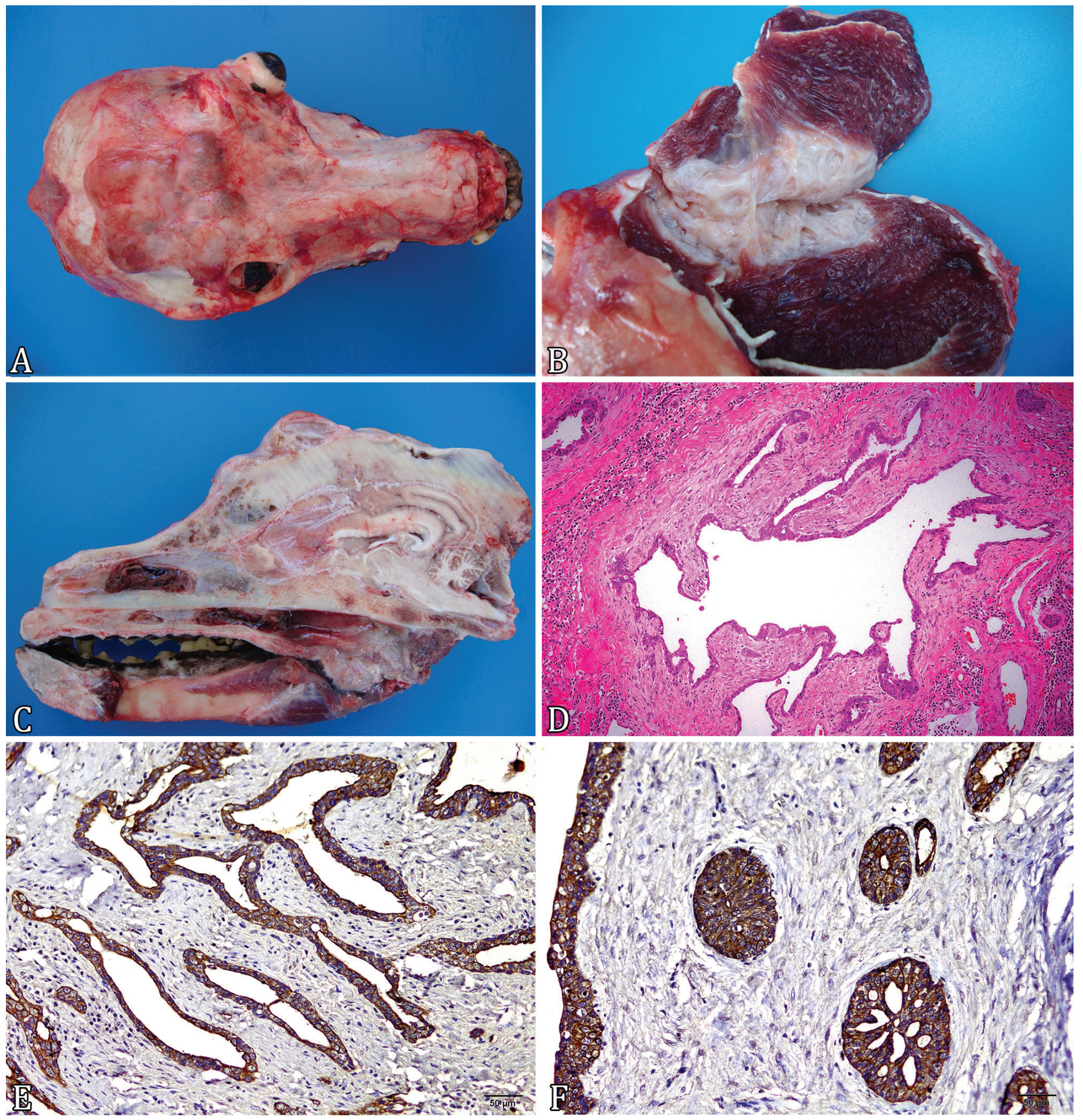

Fig.2. Adenocarcinoma of frontal sinuses. (A) Temporal region of the head with firm, cystic and coalescent nodules up to $3 \mathrm{~cm}$ in diameter. (B) The temporal muscles are invaded by the proliferation of cystic neoplasia. (C) Half-head (right side). Adenocarcinomatous proliferation is observed in the frontal sinus region. There are cystic formations that protrude, invade, and thicken the skull bones. (D) Neoplasm inside the frontal sinuses consisting of cystic epithelial formations, covered by one or more layers of cells. There are also some islands of neoplastic epithelial cells. HE, bar $=100 \mu \mathrm{m}$. (E-F) Immunohistochemistry for pan cytokeratin (streptavidin-biotin-peroxidase method). Solid islands with luminous openings (E) or cystic epithelial formations (F) are strongly immunostained. IHC, bar $=50 \mu \mathrm{m}$. 


\section{Neoplasms of other origins and round cells}

The breeds affected by neoplasms from other origins/round cells were: Siberian Husky, German Shepherd, and Dachshund (two cases). Six were mixed-breed dogs. The age of these dogs ranged from 1 to 14 years; the mean age was 8.2 years, and the median was 8 years.

Histological subtypes and the distribution of neoplasms (considering the possible site of origin, invasion, and metastasis) are shown in Table 5. Among neoplasms from other origins/round cells, seven had the nasal cavity as the probable place of origin and three in the brain. The main macroscopic and histological characteristics are described in Table 6. In three cases, deformation of the face was observed, and all of which were diagnosed as transmissible venereal tumor (TVT).

\section{DISCUSSION}

Primary neoplasms of the nasal cavity or sinuses are rarely found and rarely reported. However, among the species of domestic animals, the most affected is the canine (Stünzi \& Hauser 1976). The low frequency of occurrence of these neoplasms, according to the literature, meets the small number of cases found in 20 years in the diagnostic routine of the LPV-UFSM, where it accounted for only $0.29 \%$ of all cases of necropsies and biopsies from dogs received in the period. However, this percentage was higher than that reported by Wilson (2017), where for every 100,000 dogs, only 2.5 $(0.0025 \%)$ would have some type of nasosinusal neoplasm.

Table 2. Histological type and macroscopic and histological characteristics of nasosinusal neoplasms with epithelial origin

\begin{tabular}{|c|c|c|}
\hline Neoplasm & & Main macroscopic and histological characteristics \\
\hline \multirow[t]{2}{*}{ Adenocarcinoma } & M & $\begin{array}{l}\text { Whitish, yellowish, and brownish masses and nodules, mostly friable, soft, firm, and mostly multilobular. Cystic } \\
\text { areas when cutting. }\end{array}$ \\
\hline & $\mathrm{H}$ & $\begin{array}{l}\text { Polyhedral, cuboid or pleomorphic cells, forming acini with single or multiple layers and, sometimes, solid areas. } \\
\text { Scarce to abundant cytoplasm. Round and oval nuclei, with loose chromatin and evident nucleoli. }\end{array}$ \\
\hline \multirow[t]{2}{*}{ Squamous cell carcinoma } & M & Whitish to yellowish mass, sometimes pink or brownish, ranging from soft to firm. \\
\hline & $\mathrm{H}$ & $\begin{array}{l}\text { Polyhedral cells are grouped in cords, nests, and islands. Abundant cytoplasm. Round to oval nuclei, with loose } \\
\text { chromatin and evident nucleoli. There are areas with individual keratinization and others with the formation of } \\
\text { keratin pearls. }\end{array}$ \\
\hline Transitional carcinoma & $\mathrm{H}$ & $\begin{array}{l}\text { Polyhedral cells forming acini. The cytoplasm is abundant. Polyhedral nuclei, round or elongated, central, with } \\
\text { densely aggregated, loose, or vesicular chromatin. }\end{array}$ \\
\hline \multirow[t]{2}{*}{ Undifferentiated carcinoma } & M & Whitish with reddish areas, ranging from soft to firm. \\
\hline & $\mathrm{H}$ & $\begin{array}{l}\text { Round polyhedral cells are grouped in the mantle. Abundant cytoplasm. Round nuclei with loose to vesicular } \\
\text { chromatin and evident nucleoli. }\end{array}$ \\
\hline Neuroendocrine carcinoma & $\mathrm{H}$ & $\begin{array}{l}\text { Polyhedral cells are grouped in the mantle. Vacuolated cytoplasm. Round, oval or reniform nuclei with markedly } \\
\text { aggregated chromatin. }\end{array}$ \\
\hline
\end{tabular}

Table 3. Histological type, number of cases, and distribution of nasosinusal neoplasms with mesenchymal origin

\begin{tabular}{|c|c|c|}
\hline Neoplasm & No. of cases $(\%)$ & Distribution \\
\hline \multirow[t]{3}{*}{ Chondrosarcoma } & $4(8 \%)$ & ${ }^{\text {(2) }}$ Nasal cavity ${ }^{\mathrm{PL}}$ \\
\hline & & (1) Nasal cavity ${ }^{\mathrm{PL}}$ and hard palate ${ }^{\mathrm{I}}$ \\
\hline & & ${ }^{(1)}$ Nasal cavity ${ }^{\mathrm{PL}}$ and palate ${ }^{\mathrm{I}}$ \\
\hline \multirow[t]{3}{*}{ Undifferentiated sarcoma } & $4(8 \%)$ & ${ }^{\text {(2) }}$ Nasal cavity ${ }^{\mathrm{PL}}$ \\
\hline & & ${ }^{(1)}$ Nasal cavity ${ }^{\mathrm{PL}}$ and pharynx ${ }^{\mathrm{I}}$ \\
\hline & & 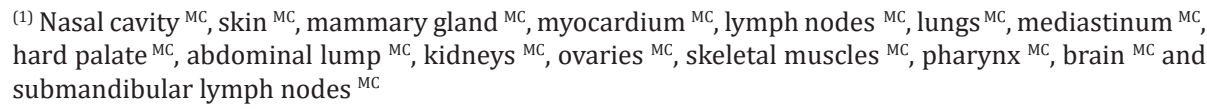 \\
\hline Osteosarcoma & $1(2 \%)$ & ${ }^{(1)}$ Nasal cavity ${ }^{\mathrm{PL}}$ \\
\hline Chondroblastic osteosarcoma & $1(2 \%)$ & ${ }^{(1)} \mathrm{Jaw}^{\mathrm{PL}}$, nasal cavity ${ }^{\mathrm{I}}$ and lung ${ }^{\mathrm{M}}$ \\
\hline Osteoblastic osteosarcoma & $1(2 \%)$ & ${ }^{(1)} J_{a w}{ }^{\mathrm{PL}}$, nasal cavity ${ }^{\mathrm{I}}$ and hard palate ${ }^{\mathrm{I}}$ \\
\hline Telangiectatic osteosarcoma & $1(2 \%)$ & ${ }^{(1)}$ Hard palate ${ }^{\mathrm{PL}}$ and nasal cavity ${ }^{\mathrm{I}}$ \\
\hline Giant cell-type osteosarcoma & $1(2 \%)$ & ${ }^{(1)}$ Nasal cavity ${ }^{\mathrm{PL}}$ and facial muscles ${ }^{\mathrm{I}}$ \\
\hline Giant cell bone tumor & $1(2 \%)$ & (1) Nasal cavity ${ }^{\mathrm{PL}}$ and oral cavity ${ }^{\mathrm{I}}$ \\
\hline Fibrosarcoma & $1(2 \%)$ & ${ }^{(1)}$ Nasal cavity ${ }^{\mathrm{PL}}$ and facial muscles ${ }^{\mathrm{I}}$ \\
\hline Hemangiosarcoma & $1(2 \%)$ & ${ }^{(1)}$ Nasal cavity ${ }^{\mathrm{PL}}$ \\
\hline TOTAL & $16 / 50(32 \%)$ & \\
\hline
\end{tabular}

(1), (2) Number of cases; PL = possible place of origin, $\mathrm{I}=$ invasion, $\mathrm{M}=$ metastasis, $\mathrm{MC}=$ multicentre; * dog had adenocarcinoma in the frontal sinuses. 
In general (including the three histogenetic categories of neoplasms), it was observed that females were slightly more affected than males (male: female ratio of 1:1.23). The frequency of involvement of mesocephalic dogs was slightly higher than in dolichocephalic dogs; brachycephalics were much less affected. Twenty-four purebred dogs, distributed in 16 different breeds, were affected. It was also observed that approximately $80 \%$ of the purebred dogs were of large and giant breeds. These results demonstrate the profile of this group of 49 dogs analyzed, not allowing to affirm any predisposition of the canine population in general. According to the literature, there is variation in the male:female relationship between studies, and it is not possible to determine whether there is a predisposition by sex (Wilson 2017). For some authors, nasosinusal neoplasms usually affect dogs with dolichocephalic cranial conformation (with a longer elongated snout) compared to mesocephalic and brachycephalic (Lobetti 2009, Rassnick et al. 2006). However, this conclusion is considered controversial (Wilson 2017). It is believed that dogs when compared to other domestic species, are more prone to the development of neoplasms in the nasal cavity. This predisposition is possibly due to epidemiological conditions, such as higher exposure to pollutants in the environment, especially tobacco smoke, burning charcoal, and kerosene heat sources(Caswell \& Williams 2016). Certain breeds have been identified in the literature as most at risk for this type of neoplasm, including

Table 4. Histological type and macroscopic and histological characteristics of nasosinusal neoplasms with mesenchymal origin

\begin{tabular}{|c|c|c|}
\hline Neoplasm & & Main macroscopic and histological characteristics \\
\hline \multirow[t]{2}{*}{ Chondrosarcoma } & M & $\begin{array}{l}\text { Masses ranging from whitish to yellowish and sometimes reddish, mostly firm and less often soft, usually with an } \\
\text { uneven surface. }\end{array}$ \\
\hline & $\mathrm{H}$ & $\begin{array}{l}\text { Cells are spindle-shaped, polyhedral, round, or oval. Cytoplasm from scarce to abundant. Oval or round nuclei, } \\
\text { elongated or reniform, with loose chromatin and evident nucleoli. Chondroid matrix formation areas. }\end{array}$ \\
\hline \multirow[t]{2}{*}{ Undifferentiated sarcoma } & M & Whitish and reddish, friable, and irregular mass. \\
\hline & $\mathrm{H}$ & Round cells grouped in the mantle. Scarce to abundant cytoplasm. Round, central nuclei with dense chromatin. \\
\hline Osteosarcoma & M & Blackened, friable, and firm or hard fragments. \\
\hline \multirow[t]{2}{*}{ Chondroblastic osteosarcoma } & M & Whitish, firm, and finely cross-linked mass. \\
\hline & $\mathrm{H}$ & $\begin{array}{l}\text { Pleomorphic cells are grouped in the mantle. Moderate cytoplasm. Round, oval or polyhedral nuclei with loose } \\
\text { chromatin and evident nucleoli. Streaked by myxoid stroma. Presence of osteoid and chondroid matrix. }\end{array}$ \\
\hline \multirow[t]{2}{*}{ Osteoblastic osteosarcoma } & M & Whitish, multilobulated, and soft mass \\
\hline & $\mathrm{H}$ & $\begin{array}{l}\text { Rounded polyhedral cells grouped in cords, groups, and mantles. Moderate cytoplasm. Round to oval nuclei with } \\
\text { loose chromatin and evident nucleoli. With a small amount of bone matrix, sometimes mineralized. }\end{array}$ \\
\hline \multirow[t]{2}{*}{ Giant cell-type osteosarcoma } & M & Reddish mass. \\
\hline & $\mathrm{H}$ & $\begin{array}{l}\text { Rounded polyhedral cells are arranged in mantles (anaplastic osteoblasts). Moderate cytoplasm. Round nuclei with } \\
\text { finely dotted chromatin and evident nucleoli. Large numbers of giant cells are observed. Interwoven with a small } \\
\text { amount of non-mineralized osteoid matrix. }\end{array}$ \\
\hline \multirow[t]{2}{*}{ Giant cell bone tumor } & M & Invasive and ulcerated mass. \\
\hline & $\mathrm{H}$ & $\begin{array}{l}\text { Polygonal and spindle cells forming mantles and spindles, respectively. Moderate cytoplasm. Oval to elongated } \\
\text { nuclei with loose chromatin and evident nucleoli. With multinucleated giant cells interspersed. Mineralized and } \\
\text { non-mineralized osteoid matrix. }\end{array}$ \\
\hline \multirow[t]{2}{*}{ Hemangiosarcoma } & M & Brownish, regular, friable, and soft plate. \\
\hline & $\mathrm{H}$ & $\begin{array}{l}\text { Fusiform and polyhedral cells are grouped in mantles, cords, and bundles. Scarce cytoplasm. Elongated and rounded } \\
\text { nuclei, central with loose chromatin and evident nucleoli. }\end{array}$ \\
\hline$\frac{\text { Neoplasm }}{\text { Transmissible venereal tumor }}$ & & ${ }^{(1)}$ Nasal cavity ${ }^{\mathrm{PL}}$, soft palate ${ }^{\mathrm{I}}$ and skin ${ }^{\mathrm{I}}$ \\
\hline Psammomatous meningioma & & (2) Brain ${ }^{\mathrm{PL}}$ and nasal cavity ${ }^{\mathrm{I}}$ \\
\hline Anaplastic meningioma & & ${ }^{(1)}$ Brain $^{\mathrm{PL}}$, nasal cavity ${ }^{\mathrm{I}}$, nasal septum ${ }^{\mathrm{I}}$, jaw bone ${ }^{\mathrm{I}}$, the lacrimal bone ${ }^{\mathrm{I}}$, and left orbit ${ }^{\mathrm{I}}$ \\
\hline Olfactory neuroblastoma & & ${ }^{(1)}$ Nasal cavity ${ }^{\mathrm{PL}}$ and brain ${ }^{\mathrm{I}}$ \\
\hline T-cell lymphoma & & ${ }^{(1)}$ Nasal cavity ${ }^{\mathrm{PL}}$, brain ${ }^{\mathrm{I}}$ and submandibular lymph nodes ${ }^{\mathrm{M}}$ \\
\hline TOTAL & & $10 / 50(20 \%)$ \\
\hline
\end{tabular}


Table 6. Histological type and macroscopic and histological characteristics of nasosinusal neoplasms from other origins and round cells

\begin{tabular}{lrll}
\hline \multicolumn{1}{c}{ Neoplasm } & & \multicolumn{1}{c}{ Macroscopic and histological characteristics } \\
\hline Transmissible venereal tumor & M & $\begin{array}{l}\text { Mostly whitish nodules and masses, sometimes reddish, soft, and multilobulated (with the appearance of cauliflower). } \\
\text { Psammomatous meningioma }\end{array}$ \\
& H & Mound cells are arranged in a mantle. Abundant and vacuolated cytoplasm (ranging from finely to markedly). Round, & $\begin{array}{l}\text { large, central nuclei with loose chromatin and evident nucleoli. } \\
\text { Masses ranging from whitish to reddish and soft in the olfactory bulb. }\end{array}$ \\
& H & $\begin{array}{l}\text { Spindle cells grouping into islands, nests, and bundles forming swirls. Moderate to abundant cytoplasm. Round } \\
\text { to oval nuclei with loose chromatin and few evident nucleoli. Among the neoplastic cells, there are concentric } \\
\text { aggregates of basophilic material (psammomatous bodies). }\end{array}$ \\
Anaplastic meningioma & M & $\begin{array}{l}\text { Irregular, soft, and whitish mass. } \\
\text { Round cells in mantle. Scarce to moderate cytoplasm with very distinct cytoplasmic limits. Round nuclei, with } \\
\text { condensed chromatin and evident nucleoli. }\end{array}$ \\
Olfactory neuroblastoma & M & Whitish, soft mass. \\
Lymphoma (T-cell) & H & $\begin{array}{l}\text { Polyhedral cells forming mantles, rosettes, and microcysts. Scarce cytoplasm with indistinct boundaries. Round to } \\
\text { oval, hyperchromatic cores with finely granular chromatin. } \\
\text { Left side: reddish to blackish soft mass with gelatinous areas. Right side: white and soft mass. } \\
\text { Round cells are arranged in mantles. Scarce cytoplasm. The nuclei are round and sometimes reniform with evident } \\
\text { nucleoli. }\end{array}$
\end{tabular}

descending order, Airedale terrier, Basset hound, Old English Sheepdog, Scottish terrier, Collie, Shetland Shepherd, and German Shorthaired Pointer (Wilson 2017).

In general, there was a wide variation in the age of the affected dogs (11 months to 16 years old). However, when separated by histogenetic groups, it was observed that the dogs affected by epithelial neoplasms had a mean and median age higher than those affected by mesenchymal neoplasms and other origins. These results are in line with those described in the literature (Stünzi \& Hauser 1976, Wilson 2017), but a specific cause for this observation was not identified.

The clinical signs described for the dogs in this study were mainly related to involvement in the upper respiratory tract, including partial or total obstruction of the nasal cavity, breathing difficulty, sneezing, presence of nasal discharge, and cough, being similar to that previously observed (Segal et al. 1986, Rocha et al. 2008, Cruz et al. 2009, Gonçalves et al. 2012, Galiazzo et al. 2017). However, attention was drawn to the frequency of dogs with neurological signs related to when the neoplasm invaded the brain and adjacent tissues or when it was primary in the brain, as in the case of the three meningiomas observed. Although nervous symptoms are described in dogs with nasosinusal neoplasms (Rassnick et al. 2006, Silva et al. 2009, Wilson 2017), brain invasion should not be ruled out due to the absence of neurological signs, because in some cases dogs may not display these signs (Turek \& Lana 2013).

As to the origin (histogenesis) of the neoplasms, the epithelial ones accounted for $16 \%$ and $28 \%$ more than the mesenchymal neoplasms and other origins/round cells, respectively, in the 49 dogs studied. In the literature, most nasosinusal neoplasms have been described as having an epithelial origin, but the percentage relationship with neoplasms from other sources has not been reported (Patnaik 1989, Lobetti 2009, Wilson 2017).

Among the epithelial neoplasms, the most frequently described, in decreasing order of prevalence, are adenocarcinomas, transitional carcinomas, and squamous cell carcinomas (SCC) (Lobetti 2009, Wilson 2017). In this study, the most prevalent neoplasms of epithelial origin were adenocarcinoma and SCC, with the same number of cases each.

Among the 16 mesenchymal neoplasms diagnosed, the highest occurrence was osteosarcomas, chondrosarcomas, and undifferentiated sarcomas; the first had five cases, and the others had four cases each. Chondrosarcomas occur mainly in flat bones, whereas osteosarcomas usually occur in the appendicular skeleton (Thompson \& Dittmer 2017). Because of this, it was believed that a higher number of chondrosarcoma cases occur when compared to those of osteosarcoma, in the nasal cavity, due to the presence of the nasal bone, which is a flat bone (Patnaik et al. 1984). However, in this study, similar numbers were observed for each of these neoplasms.

Of the ten neoplasms with other origins/round cells, half were classified as transmissible venereal tumor (TVT). This neoplasm is a tumor mainly related to the genitals, occurring mainly in the vulva, penis, and foreskin, for having its transmission during coitus (Hendrick 2017). However, dogs can acquire this neoplasm by licking, biting, and smelling another dog affected by the TVT. Because of this behavior of dogs from one sniff to another, neoplastic cells are transmitted to the nasal cavity (Woods 2013). The other cases were encephalic meningiomas that invaded the nasal cavity, olfactory neuroblastoma, and lymphoma. The latter two being neoplasms considered rare in this location (Wilson 2017).

As for cranial/facial deformation, it was observed that, among epithelial neoplasms, almost half of the cases were diagnosed as SCCs. This diagnosis indicates that this neoplasm has more destructive/proliferative tissue characteristics (with more external changes) than the other nasosinusal epithelial cell neoplasms. Among mesenchymal neoplasms, the one that caused the greatest deformities visible externally (facial and cranial asymmetries) was osteosarcoma, compared to chondrosarcoma and fibrosarcoma. As for neoplasms of other origins and round cells, the only one that caused external deformities was TVT. The other neoplasms (brain meningioma, olfactory neuroblastoma, and T-cell lymphoma) had their internal expansion in the nasal cavity, including invading the brain and vice-versa (in the case of brain meningioma). 


\section{CONCLUSIONS}

Nasosinusal neoplasms had a low frequency in the diagnostic routine. However, their occurrence is relevant because they were all malignant, regardless of histogenesis, with a higher frequency of epithelial neoplasms, followed by mesenchymal and other origins/round cells. It was possible to trace the profile of the affected dogs.

Among purebred dogs, the mesocephalics were more affected concerning dolichocephalics and brachycephalics.

There was a wide variation in the age of the dogs, but older dogs were affected by epithelial neoplasms, compared to those of other origins.

There was a predominance of nasal over sinus neoplasms, with frequent invasions to adjacent tissues, often culminating in cranial and facial deformities accompanied mainly by respiratory and nervous signs, depending on the location and extent of the neoplasm. Despite being infrequent in the diagnostic routine, nasosinusal neoplasms can be challenging to diagnose, especially in small biopsies.

Considering that these neoplasms are usually malignant, the importance of an accurate and rapid diagnosis is emphasized to establish the most appropriate treatment for the affected dog.

Acknowledgments.- The authors would like to thank the "Coordenação de Aperfeiçoamento de Pessoal de Nível Superior" (CAPES), Brazil, for the financial support.

Conflict of interest statement.- The authors have no competing interests.

\section{REFERENCES}

AKC, American Kennel Club. 2019. Dog breeds. Disponível em <https:// www.akc.org/dog-breeds/>. Acesso em: 08 jun. 2019.

Auler F.A.B. 2010. Associação da radiografia, tomografia computadorizada e rinoscopia no auxílio diagnóstico das afecções em cavidade nasal e seios paranasais de cães. Dissertação de mestrado, Universidade de São Paulo. 98p.

Bacha W.J \& Bacha L.M. 2012. Respiratory System. p.195-209. In: Bacha W.J. \& Bacha L.M. (Eds). Color atlas of veterinary histology. 3르 ed. John Wiley \& Sons.

Canal I.H., Dagli M.L.Z., Torres L.N., Piveta L.C. \& Canal R.B. 2006. TVT nasal - Tumor Venéreo Transmissível - um caso clínico. A Hora Veterinária. 26(152):15-19.

Caswell J.L. \& Williams K.J. 2016. Respiratory System. p.478-480. Nasal cavity ans sinuses. In: Jubb K.V.F., Kennedy P.C., Palmer N.C. (Eds). Pathology of domestic animals. $6^{\underline{a}}$ ed. Elsevier, St. Louis, v. 2.

CBKC, Confederação Brasileira de Cinofilia. 2019. Raças. Disponível em: <https://cbkc.org/racas>. Acesso em: 08 jun. 2019.

Cruz G.D., Santos C.F., Santos C.R., Ruschi C.S. \& Elias T. et al. 2009. Metástase visceral de tumor venéreo transmissível em cão. Veterinária e Zootecnia. 16(3):465-470.

Dadalto C.R., Inamassu L.R., Bonatelli S.P. \& Mamprim M.J. 2019. Aspectos tomográficos das neoplasias nasais em cães - estudo retrospectivo Vet. e Zootec. 26:1-7.

Evans H. \& Lahunta A. 2013. The Respiratory System. p.338-360. In: Ibid. (Eds). Miller's anatomy of the dog. $4^{\underline{a}}$ ed. Elsevier, St. Louis, Missouri.

Formighieri A.P., Cella A.C.C., Carvalho M.F., Andrioli L.G. \& Meirelles A.C.F. 2012. Adenocarcinoma nasal em cão: relato de caso. Pubvet. 6(5):1289-1294.

Galiazzo G., Pietra M., Tinto D., Linta N., Morini M. \& Capitani O. 2017. A rare case of nasal osteoma in a dog: a case report. Veterinarni Medicina. 62(11):614-619. <https://dx.doi.org/10.17221/30/2017-VETMED>
Gonçalves M.A., Corrêa L.F.D., Quevedo L.S., Schreiner T. \& Anjos B.L. 2012. Condrossarcoma primário de cavidade nasal em um cão. Acta Scientiae Veterinariae. 40(2):1042.

Hendrick M.J. 2017. Mesenchymal Tumors of the Skin and Soft Tissues: Canine transmissible venereal tumor. p.173-175. In: Meuten D.J. Tumors in Domestic Animals, 5a ed. John Wiley \& Sons, Ames, Iowa.

Junqueira L.C. \& Carneiro J. 2013. Aparelho Respiratório. p.333-352. In: Junqueira L.C. \& Carneiro J. Histologia Básica, $12^{\underline{a}}$ ed. Guanabara Koogan, Rio de Janeiro.

König H.E. \& Liebich H.G. 2011. Sistema Respiratório. p.389-410. In: König H.E. \& Liebich H.G. Anatomia dos Animais Domésticos, 4th Edit. ArtMed, Porto Alegre.

Lobetti R.G. 2009. A retrospective study of chronic nasal disease in 75 dogs. J S Afr Vet Assoc. 80(4):224-228. <https://dx.doi.org/10.4102/jsava. v80i4.212><PMid:20458862>

Ogilvie G.K. \& Larue S.M. 1992. Canine and feline nasal and paranasal sinus tumors. Vet Clin North Am Small Anim Pract. 22(5):1133-1144. <https://dx.doi.org/10.1016/s0195-5616(92)50305-9><PMid:1523785>

Patnaik A.K. 1989. Canine sinonasal neoplasms: Clinicopathological study of 285 cases. Journal of the American Animal Hospital Association. 25(1):103-114

Patnaik A.K., Lieberman P.H., Erlandson R.A. \& Liu S.K. 1984. Canine Sinonasal Skeletal Neoplasms: Chondrosarcomas and Osteosarcomas. Veterinary Pathology. 21(5):475-482. <https://dx.doi.org/10.1177/030098588402100504> $<$ PMid:6592872>

Rassnick K.M., Goldkamp C.E., Erb H.N., Scrivani P.V., Njaa B.L., Gieger T.L., Turek M.M., McNiel E.A., Proulx D.R., Chun R., Mauldin G.E., Phillips B.S. \& Kristal 0. 2006. Evaluation of factors associated with survival in dogs with untreated nasal carcinomas: 139 cases (1993-2003). J Am Vet Med Assoc. 229(3):401-406. <https://dx.doi.org/10.2460/javma.229.3.401> <PMid:16881833>

Rocha T.M.M., Terres M.F., Sotello A., Kozemjakin D., Malucelli L. et al. 2008. Tumor venéreo transmissível nasal em um cão. Rev. Acad., Ciênc. Agrár. Ambient., 6(3):349-353. <https://dx.doi.org/10.7213/cienciaanimal. v6i3.10592>

Segal K., Atar E., Mor C., Har-El G. \& Sidi J. 1986. Inverting papilloma of the nose and paranasal sinuses. Laryngoscope. 96(4):394-398. <https:// dx.doi.org/10.1288/00005537-198604000-00011><PMid:3959699>

Silva M.C.V., Nardi A.B. \& Rodaski S. 2009. Neoplasias do sistema respiratório: neoplasias das passagens nasais e seios paranasais. p.336-338. In: Daleck C.R., Nardi A.B. \& Rodaski S. Oncologia em cães e gatos, 1aㅡ ed. Roca, São Paulo.

Stünzi H. \& Hauser B. 1976. Tumours of the nasal cavity. Bull. World Health Organ. 53(2/3): 257-263. <PMid:1086156>

Thompson K.G. \& Dittmer K.E. 2017. Tumors of Bone. p.356-424. In: Meuten D.J. Tumors in Domestic Animals, $5^{\underline{a}}$ ed. John Wiley \& Sons, Ames, Iowa.

Turek M.M. \& Lana S.E. 2013. Tumors of the Respiratory System: Nasosinal Tumors. p.435-451. In: Withrow S.J., Vail D.M. \& Page R.L. Small Animal Clinical Oncology, $5^{\mathrm{a}}$ ed. Elsevier, St. Louis.

Wilson D.W. 2017. Tumors of the Respiratory Tract. p.467-498. In: Meuten D.J. Tumors in Domestic Animals, $5^{\underline{a}}$ ed. John Wiley \& Sons, Ames, Iowa.

Woods J.P. 2013. Miscellaneous Tumors: Canine Transmissible Venereal Tumor. p.692-696. In: Withrow S.J., Vail D.M. \& Page R.L. Small Animal Clinical Oncology, 5a ed. Elsevier, St. Louis. 